\title{
生体内の無機結晶性固体の研究一人体中のマグネタイト
}

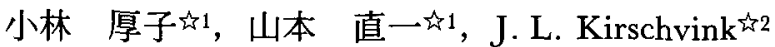 \\ 如1 京都大学大学院人間・環境学研究科，干606-01 京都市左京区吉田近衛町. 敌2 Division of Geological and \\ Planetary Sciences, California Institute of Technology, Pasadena, CA. 91125.
}

\section{Study of Inorganic Crystalline Solid in Biosystem-Magnetite in Human Body}

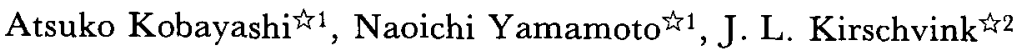 \\ 41 Graduate School of Human and Environmental Studies, Kyoto University, Yoshida-Nihonmatsu-cho, \\ Sakyo-ku, Kyoto 606-01. \$2 Division of Geological and Planetary Sciences, California Institute of \\ Technology, Pasadena, CA 91125.
}

Received May 14, 1996

\section{SYNOPSIS}

Ferritin, the iron storage nonhaeme-proten contains a ball of hydrated iron oxides (Fe2O3 $\mathrm{nH} 2 \mathrm{O}$ ) in its core, which is paramagnetic at room temperature. It is reported the hydrated iron oxide is the precursor of magnetite $\left(\mathrm{Fe}_{3} \mathrm{O} 4\right)$ in the magnetotactic bacteria and polyplacophoran mollusks. It is not known whether this is the case for other organisms. In our study, we report the first detection of magnetic material in the human brain through the use of SQUID magnetometry. The material was characterized by HRTEM and EPMA. It was affirmed the material was a single crystals of magnetite. Magnetite distribution in tissues might be related with ferritin, if the core of these molecules are involved in magnetite formation in human. In general, both Perls staining and MRImaging methods are adopted routinely for determining the relative amounts of $\mathrm{Fe}(+$ III $)$ in the whole brain, which is dominated by ferritin. Both methods suggested high levels of $\mathrm{Fe}(+$ III) distribution in the globus pallidum, putamen, caudate, internal cerebral capsule of the cerebrum, red nudeus of the mid brain and lower concentrations in the substan tia nigra of the mid brain and the dentate nucleus of the cerebellum. Whereas, ou r experiments showed that the distribution of magnetite is rather even in the whole human brain averaging $4 \mathrm{ng}$ per gram of tissue (except for the meninges, where it is 20 times higher).

\section{KEY WORDS}

Biomineral, magnetite, human brain, Perls staining, SQUID magnetometory.

\section{1 緒論}

近年になって細胞内にフェリ磁性体結晶マグ ネタイト (Fe3O4)を生成する生物が次々と発見さ れている.これまで, 磁性体結晶の抽出, 結晶構造同 定までできた生物として，ひさら貝（学術名：

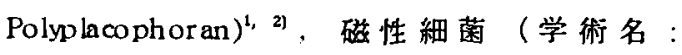

Magnetospirillum) $)^{3)}$, 磁性細菌に似た鎖状のマグ ネタイト微粒子を前頭部シ骨部内に形成する 鮭、鲔"が挙げられる、ひざら貝の曾は菌舌部分 過程で菌の成熟が准み菌の表面の色が变わる゙． 初期段階では，宷は鉄を含まないタンパク質とキチ ン質で滿ちた透明な色をしており、タンパク質フェ 
リチンが蓄積されるにつれ，非晶質含水酸化鉄 $\left(\mathrm{Fe}_{2} \mathrm{O}_{3} \cdot \mathrm{nH} 2 \mathrm{O}\right)$ の濃い赤色を带びていく. 最終 的に鉄イオンが檖元を受けマグネタイトに変わる と、それと共に歯は黒い色を呈する。磁性細菌は， 細胞内にリン脂質の膜で覆われた鎖状のマグネタ イト微粒子を形成する，初期段階で，リン脂質の液 胞内に非晶質含水酸化鉄が蓄積され，次に結晶質含 水酸化鉄を経て鎖状にならんだマグネタイトに変 わる.これ等の報告より，含水酸化鉄は生体で形成 されるマグネタイトの先駆体と考えられて拉りの゙》。 鉄供給源として細胞内のフェリチン，或いは前駆体 のような物質の存在は，マグネタイトがヒト細胞内 で形成される可能性を示唆している.

脳全体の相対的鉄濃度の測定 ${ }^{8,9 て ゙ は ， M R ~}$ Imaging法とPerk staining 法 ${ }^{10,11}$ とが通常使用され ている.MR Imaging 法では, 写像強度は, 水分子の 水素の核の緩和時間に依存する，緩和時間は，常磁 性透移金属イオンが存在すると磁気双極子相互作 用をうけて減少する ${ }^{121}$ 。この機構による緩和時間は T2 と表わす. 生体内において室温で磁性金属イ才 ンを含むものに，酸素供給の働きをするへムタンパ ク質へモグロビン, ミオグロビン，鉄貯葴の働きを する非へムタンパク質フェリチン等がある．MR Imaging 法では,緩和時間の隇少を画像に写出すこ とによって細胞組織内の常磁性物質の有無を調へ ることができる.上に述べた鉄イオンを含むタンパ ク質中の水素の T2 值はすべて短くなるが, フェり チンに含まれる鉄イオンの量がへモグロビンより 大きい為, 脳のMR Imaging 法の画像では, T2 への

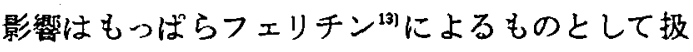
われている（この場合T2は常磁性塩からのみ奇与 していると仮定されている.)

式による錯塩形成による反応で青色に発光さ せ，その濃淡より相対的分布を調べる方法である。

\section{$\mathrm{Fe}^{3+}+[\mathrm{FelI}(\mathrm{CN}) 6]^{4+} \longrightarrow$ $\mathrm{Fe} 4[\mathrm{Fe}(\mathrm{CN}) 6] 3 \cdot \mathrm{nH}_{2} \mathrm{O} \quad$ （濃青色沈殿）}

非へムタンパク質フェリチンの 3 価の鉄イオ ンはこれを酸で溶解させることにより決定する.

これらの方法を用いた脳内の 3 価の鉄イオン， フェリチン分布については従来数多くの研究報告 がある.
本研究は, 最初の試みとして, ヒト体内, 特に脳 における强磁性体，特に鉄化合物の有無の検証を行 い,従来報告されている脳内におけるフェリチンの 分布との関連性について報告する。

\section{2 試料および实験方法}

マグネタイトの分布とキ+ラクタリゼーション について検討した.ヒトの䐯稩胞組織各部位の残留 磁化曲線を求めて,これより各部位での強磁性体の 量を推量すると共に，この物質を抽出し，HRTEM： EPMAにより結晶同定を試みた。

なおすべての実験は, 磁気シールド室 ${ }^{(4)}$ 内 $(4.2 \times 3$. $3 \times 2.8 \mathrm{~m}^{3}$, 室内漏洩磁場 約 $150 \mathrm{nT}$ ) で行なわれた。

\section{1 試料}

ヒトの脳組織と䯣膜より大脳皮筫近㥬と小脳の 組織を得, その他に大脳, 大脳基底核群, 脊娟有硬膜. 中脳。小脳テント(一例のみ)の各部位を入手した。 （標本試料は，死後12一24 時間経過した検死解剖 済みの8 体より摘出, $36-88$ 才, 男 5 体,女 4 体,内 4 体はアルツハイマー病 4病歷を有す. 南カリフォ ルニアアルツハイマー病研究センター協会 : The Alzheimers's Disease Research Center Consortium of Southern California：の好意により提供を受け た.)

\subsection{1 試料処理}

試料組織（髄膜と脳組織）から毛細血管を取り除 いた後っこれを磁気測定に可能な大きさ（約 $5 〜 25$ g）に分別した. 蒸留水で充分洗浄した後, 試料を液 体チッ素に直接浸透し，固形化した，5gに満たない 砕けた組織は，少量の蒸留水とともに水用容器にい れ同様に固形化した. またSQUIDのブランクテス ト用として, 約15〜18 gの角状の米を用いた。

\section{2 実験器具, 溶液}

試料処理, 抽出作業の際に外部からの強磁性体不 純物の混入を防ぐために下記の様な処置をおこな つた.

\section{2 .1 器具}

試料処理用の容器及び器具は，セラミックナイ フ,ガラスピペット,テフロン製ビンセット,ハイレ ックスガラス器具, ナイロン系等非金属製品を使用 した. またTEM 用のピンセットはチタン製を使用 した.これらの容器, 器具は2N HClに2 日間浸した 後, 蒸留水洗浄, 自然乾燥させた.ガラスピペットは, 
その先を熱して丸くし.ガラス粉の試料への混入を 避けた. 抽出の際に, パイレックス製計量瓶をFig.2 に示されるように細工したものを使用した.すなわ ち, 計量瓶はその高さの約 $2 \beta$ の長さのガラス管の 先端の底が平たくなるように閉じ, ふたの中央にそ のガラス管の直径と同じ大きさの穴を開け，ふたの 内側からガラス管を溶接した.

\section{2 .2 蒸留水, 溶剂液}

蒸留水は, イオン交換水を 3 度蒸留して得られた ものを使用した. 細胞組織溶解郕液 (市販:Beckman tissue solubilizer: 水酸化アンモニウム:メチルベン ゼン; $1: 5$ vol. ) およびメチルベンゼンは, 容器の底 に5 cm四方のNd FeBの磁石を数週間置いてあらか じめ強磁性体粒子を除去したものを使用した. 更に 使用する前に磁石を近づけ, 光学顕微鏡で強磁性体 粒子が完全に除去をされていることを再度確認し た.

\section{2 .3 粒子抽出}

Fig.3に示される計量瓶のガラス管にNdFeB 磁石 棒を挿入し, 試料と細胞組織溶解剤液を加え, 室温 で擋拌し細胞組織を溶解させた. 細胞組織が完全に 溶解した後, 微量の固体がガラス管先端部に付着す る(Fig.3).これをメチルベンゼンで数回洗浄した 後, 管内の磁石を抜き取り, 先端に付いている粒子 を約 $0.25 \mathrm{ml}$ のメチルベンゼン中に移した. 更に粒 子をルビーの擋挷棒(自製)で機械分散した後, ガ

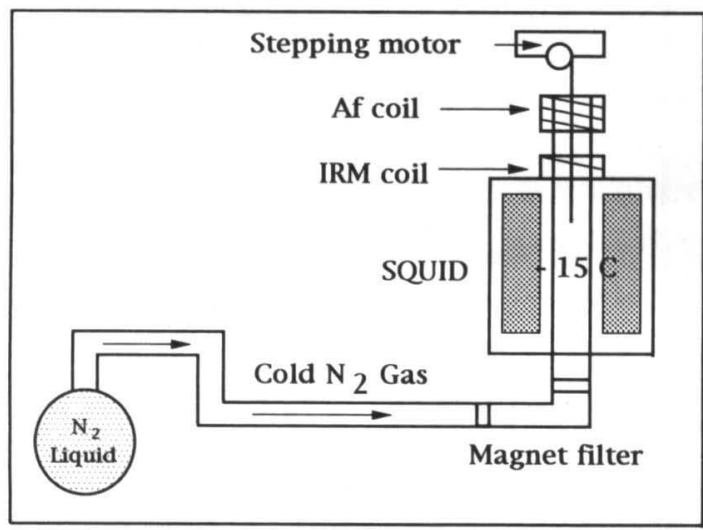

Fig.1 Schematic diagram for magnetic measurements in the magnetically shielded clean room. IRM: isothermal remanent magnetization. Af of SIRM: the progressive alternatig field demagnetization of the saturation IRM.
ラスピペットで分散液を吸い上げ。カーボン膜 TEMグリッド上に滴下し, 自然蒸発させた.

\section{3 装置及び操作}

\subsection{1 测定装置}

磁化測定装置として, SQUID(2-G En terprises社 製、試作品）を使用した. IRM コイル（自製）及 びAf コイル(2-G Enterprises 社製) をFig.1の様に 設置されている.

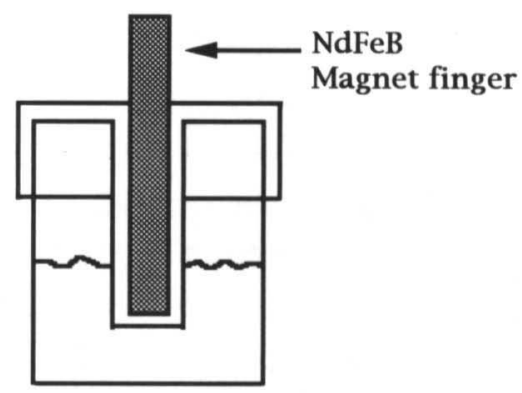

Fig.2 Magnetic finger modified from a weighing vial for extracting magnetic material from solutions.

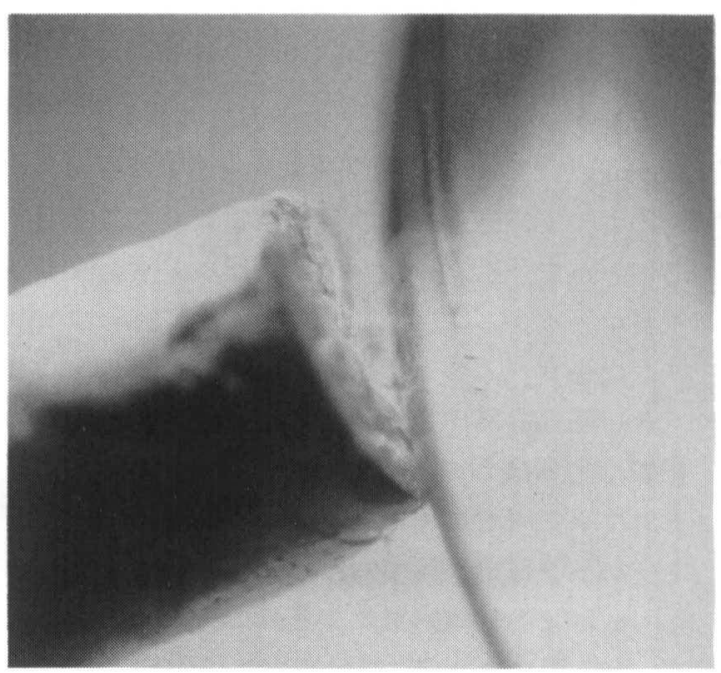

Fig. 3 Black strings of aggregated magnetic particles extracted from cerebellum tissue are viewd under low power through an optical dissecting microscope. These are collected at the focus of the magnetic finger device.

\subsection{2 操作}

試料はナイロン系で固定され, ステッピングモー ターを用いてAf, IRM コイルと測定部間を移動す ろ. 最初に100 mT で試料を磁化した後SQUID で 
測完した. 続いてAFコイルで試料を消磁(0 2 200 $\mathrm{mT}, 25$ ステップ), IRM コイルで逐次印加磁場を変 化させ,磁化(0〜631 mT, 25 ステップ) を測定した。

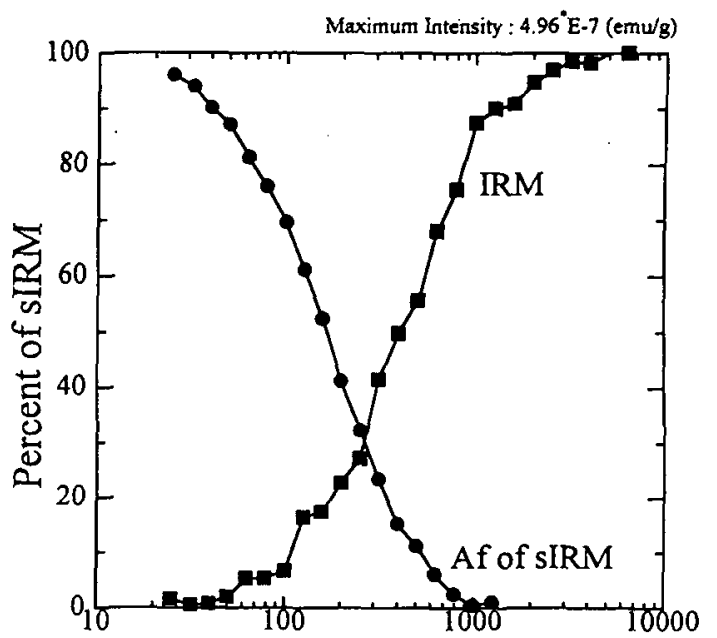

(A) Applied magnetic field(gauss)

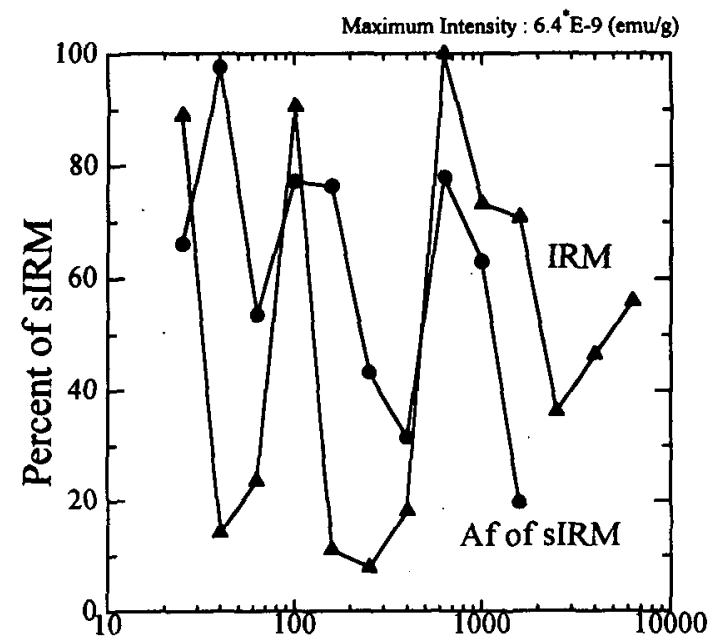

\section{(B) Applied magnetic field (gauss)}

Fig.4 Magnetic properties for tssues. representative brain cerebellum samples. (B) distilled, deionized water. The curves show the relative remanent moments in the samples after a brief exposure to the indicatd applied fields.

残留磁化值（IRM）の測定から残留磁気曲線を求 ぬた．测定中は，測定器底部から冷却したチッ素ガ スを流しSQUID内を $-15^{\circ} \mathrm{C}$ に保った。

なおブランクテストとして, 各試料の測定前後に前 述の氷のIRM値を測定した
粒子観察及び組成分析にはそれぞれ TEM (Philips, 社製, EM 430), EPMA(EDAX 社製、9900) を使用した.TEMグリッドは,銅製, 200メッシュ,ま たカメラ定数の補正試料には金蒸着膜を使用した。

Table 1 Saturated IRM values of the different tissue parts from one patient.

\begin{tabular}{|l|lll|}
\hline Tissue & $\begin{array}{l}\text { Saturated } \\
\text { IRM } \\
\left(\mathrm{nA} \cdot \mathrm{m}^{2}\right)\end{array}$ & $\begin{array}{l}\text { Weight of } \\
\text { tissue } \\
(\mathrm{g})\end{array}$ & $\begin{array}{r}\text { Saturated IRM } \\
\text { per gram of tissue } \\
\left(\mu \mathrm{A} \cdot \mathrm{m}^{2} / \mathrm{kg}\right)\end{array}$ \\
\hline No.B103993 & & & \\
Cerebral cortex & 2.4 & 9.1 & 0.26 \\
Basal ganglia & 0.842 & 12.36 & 0.068 \\
Parietal lobe (1) & 1.075 & 4.5 & 0.235 \\
Frontal lobe (1) & 0.518 & 7.34 & 0.076 \\
& 1.93 & 6.0 & 0.32 \\
Occipital lobe & 1.7 & 0.8 & 2.125 \\
Temporal lobe & 1.24 & 11.0 & 0.113 \\
Mid brain & 6.3 & 9.67 & 0.65 \\
Cerebellum & 0.205 & 1.84 & 0.143 \\
With medial posterio & 1.31 & 6.27 & 0.079 \\
With dentate & 1.39 & 15.03 & 0.925 \\
Lateral borde & 1.27 & 9.10 & 0.138 \\
Pia & & & \\
Temporal lobe & 1.198 & 0.46 & 2.604 \\
Cerebellum (1) & 2.7 & 0.63 & 4.28 \\
Frontal lobe & 4.90 & 1.53 & 2.95 \\
Parietal & 1.27 & 0.8 & 1.90 \\
Dura & 0.729 & 1.00 & 0.729 \\
Spinal & & & \\
Brain matter & 1.25 & 4.0 & 0.31 \\
\hline & 1.23 & 5.91 & 2.08 \\
\hline
\end{tabular}

\section{3 骞験結果}

\section{1 マグネタイト分布}

Fig.4(A) に磁気測定による脳試料の残留磁化曲 線の一例を示す.縦軸は比残留磁化 (Af 又はIRM $/ \mathrm{sIRM})$ を, 横軸は印加磁場の強度 $(0 \sim 631 \mathrm{mT})$ を 示す.

IRM 曲線とAf曲線が外部磁場 $25 \mathrm{~m}$ T付近で互いに 对称的になり，直楾勾配は仍るかで，また外部磁 場約 300mT でIRM值は飽和に達している。

Fig.4 (B) は, ブランクテストの測定結果を示す. 残 留磁化曲線に执いて, 試料 $1 \mathrm{~g}$ 当たりのsIRM值は， 外部磁場が $600 \mathrm{mT}$ で $0.01 \sim 0.04\left(\mu \mathrm{A} \cdot \mathrm{m}^{2} / \mathrm{kg}\right) の$ 篩囲にあり, 朕試料の sIRM値の約百分の一の值 を示す。これより，脳試料に微量の強磁性体が存在 すると推定した. Table 1は一標本における脳組織 sIRM の測定值である. 髄膜を除く脳細胞の単位グ ラム当たり $\mathrm{sIRM}$ 測定侹の平均は, $0.21(\mu \mathrm{A}$. $\left.\mathrm{m}^{2} / \mathrm{kg}\right)$ で, 髄膜では3.33( $\left.\mu \mathrm{A} \cdot \mathrm{m}^{2} / \mathrm{kg}\right)$ であり, 大脳, 中 脳，小船の各測定部位の間に顕著な差はなかった。 

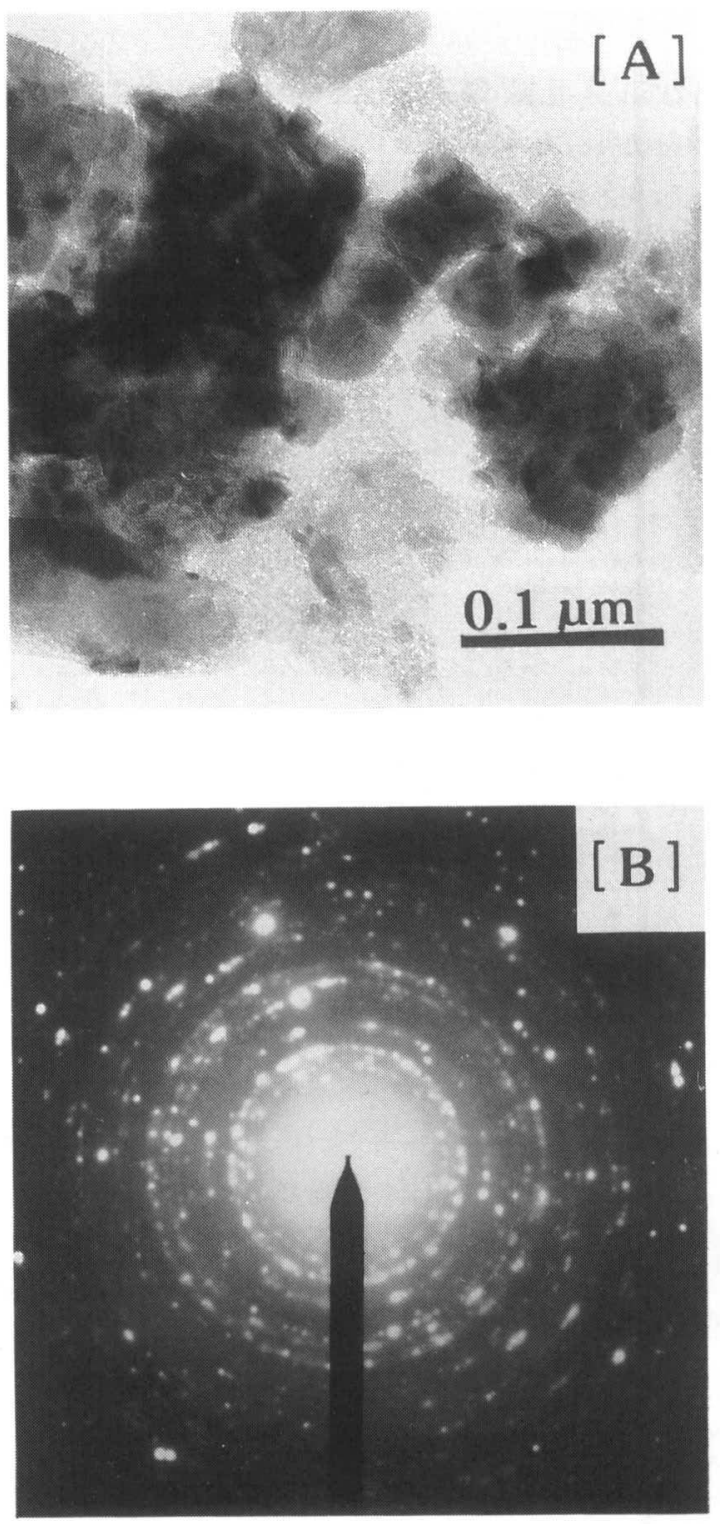

Fig 5( A) TEM images of crystal morphologies of an extracted aggregate of magnetic particles. 5(B) The diffraction rings from the crystak shown in (A)confirms $\mathrm{Fe}_{3} \mathrm{O}_{4}-\gamma \mathrm{Fe}_{2} \mathrm{O}_{3}$ identification.

\section{2 電子顥微鏡写像と結晶同定}

Fig. 3 に大脳組織 $40 \mathrm{~g} よ り$ 抽出された粒子の集合 の光学顕微鏡写真を示す. 黒色の粒子は針状の集団 を形成している.これは, 磁気走行性バクテリアか ら抽出した磁性体粒子を, 同じ様に観察した時の状 態と類似している.

Fig.5(A) は抽出粒子のTEM写真を示す. 粒度は,

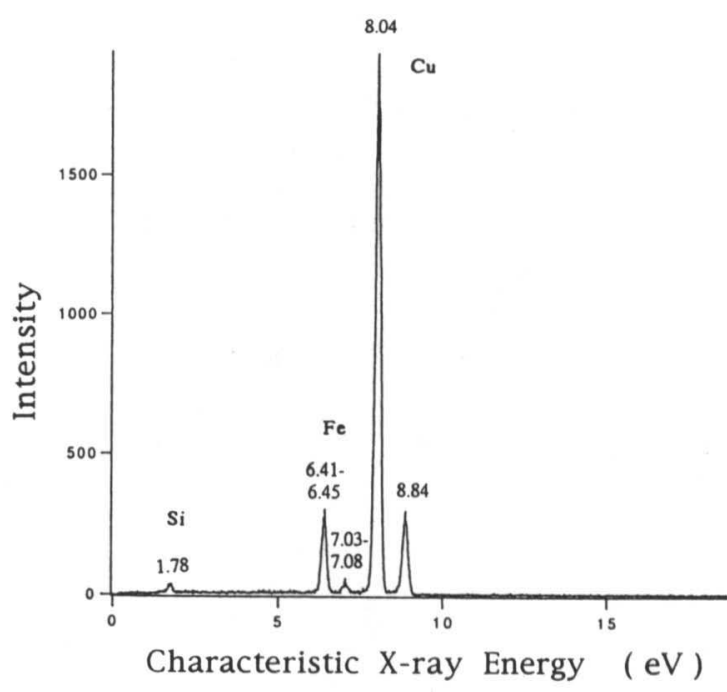

Fig.6 Characteristic $x$-ray energy data of a clump of small particles from the cerebellum, by energy dispersive $\mathrm{x}$-ray analysis.

70 個の粒子の中で 62 個は直径 $10 \sim 70 \mathrm{~nm}$ 範囲に あり (平均 $33,4 \pm 15,2 \mathrm{~nm}$ ), 他の 8 個は直径が 90 200 nm の範囲にある. Fig.6(B)及びFig.6にFig.5 (A) で示された粒子の電子線回折像およびEPMA の測 定結果を示す. EPMA では純粋な Fe によるピーク の他に極微量のSi によるピークのみが観察された （CuピークはT E Mグリッドによる）.

これより, 試料は殆ど Feのみを含む化合物とかん がえられる.

Fig.7はFig.8にある集合粒子の指数付けされた電 子線回折像を示す.これらの回折像より, 粒子はス ピネル型結晶構造を持つ強磁性体マグネタイト $\mathrm{Fe}_{3} \mathrm{O}_{4}$ (より正確には,鉄の酸化が進んだ $\gamma-\mathrm{Fe}_{2} \mathrm{O} 3$ ) であると考えられる。

Fig.8 は小脳から抽出したマグネタイトの格子像 ある. Fig. 8 に示す回折像と同じ結晶方位 $<211>$ で ある. 格子間隔 $4.85 \AA$ をもつ(111) 面がでている.

\section{4 考察およびまとめ}

ヒトの脳と脳䯣膜から強磁性体物質マグネタイ トーマグヘマイト $(\gamma-\mathrm{Fe} 2 \mathrm{O} 3)$ を検出, 結晶を抽 出することができた，

試料内の強磁性体粒子は, 1) 保磁力を表わす残留 磁化曲線の交差点が, すべての試料で12 mT（軟 膜）から $50 \mathrm{~m} \mathrm{~T}$ (大脳基底核郡) の範囲（平均保磁 


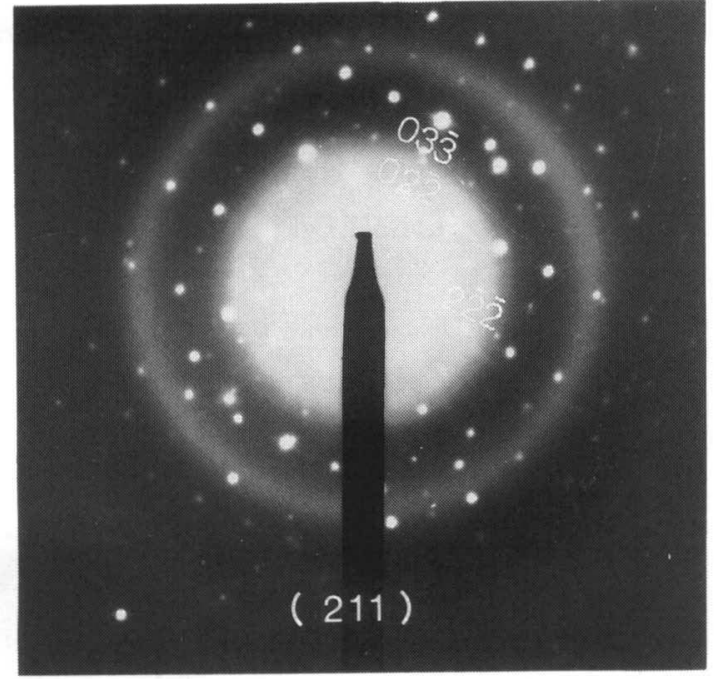

Fig.7 The indexed selected-are a electron diffraction spot pattern of one of these crystals, taken in the $<211>$ zone the fringes of the mixture of odded and even numbers indicate the partial oxidation to maghemite.

カが $30 \mathrm{mT}$ )にあり単一磁区マグネタイトの理論値 内にある.2) 磁性細菌から得られたマグネタイト粒 子による残留磁化曲線の直線勾配(残留磁化曲線の 交差点を原点にして）は 8.2 付近（未発表）である が, 試料による直線勾配は, 2.7 付近とゆるやかであ る.これらより, 単一磁区をもつマグネタイトで, 磁 性細菌内のマグネタイト粒子より粒子径にばらつ きをもつと判明された. 粒度分布ばらつきにおいて はTEM 写真観察による粒径測定と一致する. 得ら れた標本の平均 sIRM 測定値は, 髄膜で $333(\mu$ $\left.\mathrm{A} \cdot \mathrm{m}^{2} / \mathrm{kg}\right)$, それ以外の脳組織では0.21 $\left(\mu \mathrm{A} \cdot \mathrm{m}^{2} / \mathrm{kg}\right)$ と大脑, 中脳, 小脳の各測定場所に差はみられなか ったので, マグネタイトは脳内に均一に分散してい ると考えられる。东た,マグネタイト $1 \mathrm{~g}$ 当たりの $\operatorname{sIRM}$ 值は $46 \times 10^{-3}\left(\mathrm{~A} \cdot \mathrm{m}^{2}\right)$ であるので,脳組織 $1 \mathrm{~g}$ 当 たり $456 \mathrm{ng}$ のマグネタイトが含有すると推定され た。

脳内の強磁性体粒子分布とPerk staining 法によ 万鉄イオン相対濃度分布との違いを考察してみる ヒトの脳内のフェリチン相対濃度分布 ${ }^{8)}$ では, 大脳 では淡荅球外側部, 内包, 被殼, 尾状核頭, 後頭葉の 皮質, 中脳では黒質, 赤核, 小脳では, 歯状核が他の

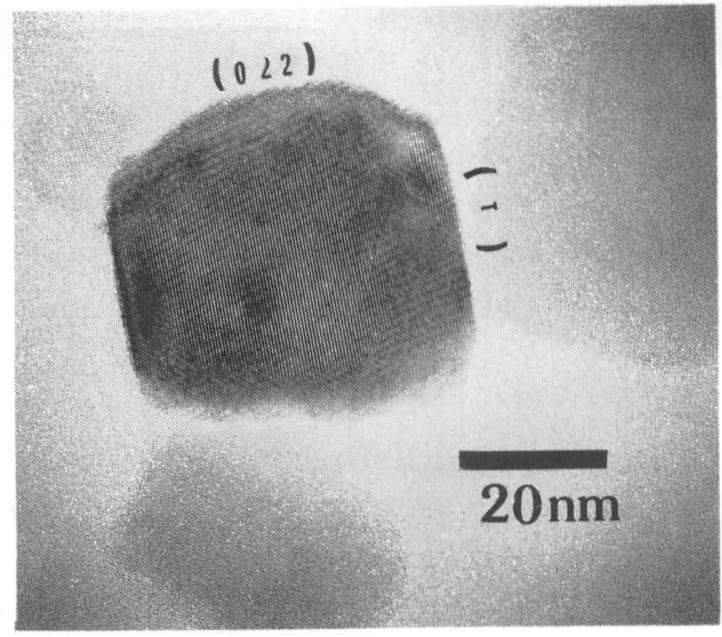

Fig.8 TEM images of a chump of small maghemite crystals showing the pattem of intersecting $\{111\}$ and $\{022\}$ lattice fringes.

脳内の強磁性体粒子分布とPerk staining 法によ る鉄イオン相対濃度分布との違いを考察してみる。 ヒトの脳内のフェリチン相対濃度分布 ${ }^{\text {8) }}$ では淡荅球外側部, 内包, 被殼, 尾状核頭, 後頭葉の 皮質, 中脳では黒質, 赤核, 小脳では, 歯状核が他の 場所と比べてフェリチンが多く分布することが報 告されており, その偏在を示している. 脳内のマグ ネタイトは均一に分布しているという本実験結果 と異なっていることが見い出された.アポフェリチ ン空洞内に含水酸化鉄を蓄積するフェリチンは, マ グネタイト形成段階で, ひさら貝の歯の成長時に生 成される含水酸化鉄や, 磁性細菌内の粒子形成段階 で蓄積される非晶質含水酸化鉄に重要な役割を果 たしている5, 16) と考えられている. 脳内のフェリチ ン分布とマグネタイト分布が一致しない本実験結 果は, 脳組織で検出されたマグネタイトは生体細胞 によるものであるがフェリチン先駆体である可能 性が少ないことを示唆している. しかし脳内のフェ リチン 存在量 ${ }^{17,18)}(0.3 \sim 7 \mu \mathrm{g} / 1 \mathrm{~g}$ brain tissue) とマグ ネタイトの含有量 $(4 \mathrm{ng} / \mathrm{lg}$ brain tissue) がかなり違 うので, フェリチンとマグネタイトの分布の明確な 相関関係が得られていない要因にもなっている

放射性指示薬 $\mathrm{Fe}^{59}$ を用いた実験"1 により血液に 異端子として注入されたマグネタイトの鉄は代謝 
されフェリチン内に蓄積されていくこと, および鉄 の還元と透析によって含水酸化鉄を取り除いたア ポフェリチン空洞内に, マグネタイト結晶を形成さ

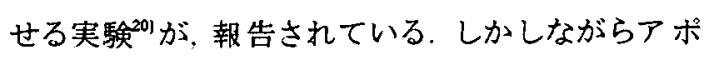
フェリチン内に形成される含水酸化鉄と細胞内で のマグネタイト粒子形成の関連性については今後 の残された研究課題である.

\section{謝辞}

脑標本の提供に御尽力をいただきました南カリ フォルニア大学医学部 Carol Miller 博士, カリフォ ルニア工科大学材料研究センターBrent Fultz 博士 並びに Carol Garland 技官に心から謝意を表しま す. 本研究の一部は National Institute of Health Grant GM-41635, National Science Foundation Grant DMR-8811795 の援助で行われました.

\section{文献}

1)H.A.Lowenstam:Science, 156(1967)1373.

2)H.A.Lowenstam,S.Weiner:Science, 227 (1985) 51.

3)S.Mann,N.H.C.Sparks,Board,R.G.Board: Adv. Microb.Physiol.,31(1990) 125.

4)S.Mann,N.H.C.Sparks,M.M.Waker,J.L.Kirschvink : J.Exper.Biol.,140 (1988)35.

5)H.M.Nesson, A.H.Lowenstam: A new biomagnetisn,,(eds.) J.L.Kirschvink,D.S. Jones, J.Macfadden: Plenum Press New York,(1985)333.

6)Y.Tamaura,K.Ito,T.Katsura: J.Chem.Soc.Dalton Trans., (1983)189.

7)S.Mann: Nature,36 (1993)499.

8)B.Drayer,P.Burger,R.Darwin,S.Riederer,R.Hertk
ens,G.A.Johnson: A.J.N.R.,7(1986)373.

9)A.Bizzi,R.A.Brooks,A.Brunetti,J.M.Hill.J.R.Alger, R.S.Miletich,T.L.Francavilla,Di Chiro Giovanni: Radiology,177(1990)59.

10) J.P.Cassella J.Hay,M.T.Ball: Proc.Roy.Micros Soc.,25(1990)41.

11) J.P. Cassella J.Hay: Metal iron in biology and medicine,(eds.)Ph.Collery,L.A.Poirier,M.Manfait,J . C.Etienne: John Libbey Eurotext,Paris,(1990) 104.

12)R.B.Lauffer: Chem.Rev.,87(1987) 901.

13)S.H.Koening: Iron biominerals,(eds) R.B. Frankel,R.Blakemore: Plenum Press N.Y.,(1990) 359

14)G.R.Scott,C.Frohlich: A new biomagnetism. (eds.)J.L.Kirschvink,D.S.Jones,B.J.Macfadenn:

Plenum Press, New York,(1985) 197.

15) M.Fuller,W.S.Goree,W.L.Goodman:A new biomagne tisms.(eds.) J.L.Kirschink,D.S. Jones BJ. Macfadenn: Plenum,New York. (1985) 103.

16)R.B.Frankel,G.C.Papaefthymiou,R.P.Blakemore ,W.O' brien:Biochim.Biophus.Acta., $763 \quad$ (1983) 147.

17)B.Hallgren,P.Sourander: J.Neurochem..3 (1958) 41.

18)J.F.Schenck,O.M.Mueller,S.P.Souza,C.L.Dumou lin: Ironbiominerals (eds.)R.B.FrankelR. P.Bla kemore,Plenum Press,N.Y..(1990)373

19)E.Okon, D.Pouliquen,P.OkoB.N.Kudryavts ev,P.Jallet: aboratory investigation, 71 (1994) 895. 20) F.C.Meld rum,B.R.Heywo od,S.Mann: Science, 257 (1992)522. 